\title{
EJAKULASI PREMATUR SEBAGAI ALASAN PERCERAIAN MENURUT KOMPILASI HUKUM ISLAM (KHI) DAN FIQH SYAFI'IYAH
}

\author{
Nurhayati Zein \\ Fakultas Tarbiyah dan Ilmu Keguruan UIN Suska Riau \\ E-mail: nurmeicil@yahoo.com
}

\begin{abstract}
One of the sexual harassment experienced by the husband is premature ejaculation. This disorders can distrub the harmonisation of husband-wife relationship because one is experiencing premature ejaculation cannot give sexual satisfaction to his wife. Thus, the purpose of marriage is to establish sakinah, mawaddah and mercy familiy will not be realized due to unpay of the rights and obligations. In the Compilation of Islamic Law, premature ejaculation is included as the reason for wife to ask divorce, in Islamic term it called 'khulu'. While the Shafi's mazhab, premature ejaculation can be as a reason to give fasakh. Although, "khulu " and 'fasakh" are icluded as the reasons for divorce, but both have different legal effects. In the hadith of 'khulu', it was said that 'khulu' does not do due to unperfect husband to fulfill the sexual need of wife or husbund leave his obligations. It is more ampasize on un pleasuare wife toward the husband which will ditrub the harmonisation in the household.
\end{abstract}


Kata kunci: ejakulasi prematur, perceraian, Kompilasi Hukum Islam (KHI), Syafi'iyyah

\section{PENDAHULUAN}

Perkawinan merupakan wadah penyaluran kebutuhan biologis yang dihalalkan dan merupakan sunnatulllah dan rasul-Nya yang bertujuan untuk membentuk rumah tangga yang sakinah, mawaddah dan rahmah. Hal ini dinyatakan dalam firman Allah dalam surat al-Ruum ayat 21:

\%[ํurø r\& öNä3ÅjàÿRr\& ô’ÏiB /ä3s9 t,n=y\{ ㅎbr\& ÿ3/4ÏmÏG»t \#uä ô'ÏBur $4{ }^{\circ}$ pyJômu ur Zo“ uq"B Nà6uZ $\div$ t/ @yèy_ur \$ygø s9î) (\#pqãZä3óitFİj9 ÇËÊÈ tbrã (C)3xÿtGt 5Qöqs)Ïj9 ;M»t Uy y7ї9º $\quad$ Îu "bî) Artinya: Dan di antara tanda-tanda kekuasaan-Nya ialah Dia menciptakan untukmu isteri-isteri dari jenismu sendiri, supaya kamu cenderung dan merasa tenteram kepadanya, dan dijadikan-Nya diantaramu rasa kasih dan sayang. Sesungguhnya pada yang demikian itu benar-benar terdapat tanda-tanda bagi kaum yang berfikir.

Guna mencapai tujuan perkawinan tersebut, suami dan istri harus melakukan hak dan kewajibannya secara baik dan benar. Diantara kewajiban suami adalah memberikan nafkah kepada istri, baik berupa nafkah lahir maupun nafkah batin. Nafkah lahir antara lain adalah berupa sandang, papan, dan pangan. Nafkah bathin diantaranya adalah dalam bentuk memberikan kepuasan seksual, karena kehidupan seks merupakan kebutuhan naluriah dan alamiah yang memerlukan penyaluran untuk memperoleh kesenangan.

Dalam melakukan hubungan seksual, kepuasan suami harus diperhatikan dengan tidak mengabaikan kepuasan istri. Artinya, kepuasan kedua belah pihak perlu diperhatikan dengan sungguhsungguh, sebagaimana yang dijelaskan Allah SWT. dalam al-Qur'an Surat Al-Baqarah ayat 187

3 £’ßg@9 Ó“\$t6Ï9 öNçFRr\&ur öNä3@9 Ó“\$t6Ï9 £’èd Artinya: Mereka adalah pakaian bagimu, dan kamupun adalah pakaian bagi mereka.

Dipahami dari ayat di atas bahwa suami istri satu sama lain haruslah saling melengkapi dalam hidup berumah tangga. Begitu pula halnya dalam hubungan seks yang merupakan kebutuhan biologis yang 
harus dipenuhi, maka seharusnyalah suami istri memperhatikan kebutuhan masing-masing pihak.

Jika kebutuhan seks ini tidak terpenuhi secara maksimal, maka akan dapat mempengaruhi kehidupan berumahtangga. Kebutuhan seks istri yang tidak terpenuhi secara maksimal dapat disebabkan karena suaminya mengalami ejakulasi premature, yakni "terlalu cepat selesai" sehingga istri merasa tersiksa. Hal ini bisa mengakibatkan istri mudah emosi, acuh terhadap suami, stress, kecewa, menyalahkan diri sendiri, bahkan takut melakukan hubungan seksual karena dibayangi rasa ketakutan akan gagal lagi.

Suami yang mengalami ejakulasi prematur, tetap mempunyai dorongan seksual, tetapi di waktu terjadinya coitus suami tidak mampu mempertahankan ejakulasi. ${ }^{1}$ Hanifa Wiknjosastro mengemukakan bahwa ejakulasi prematur adalah pengeluaran sperma yang terlampau cepat.

Ejakulasi prematur terbagi dua; pertama, ejakulasi prematur yang sementara yaitu pengeluaran sperma yang terlampau cepat pada waktu dan keadaan tertentu yang tidak dapat dikendalikan, bersifat sementara ini sering terjadi pada coitus pertama setelah lama absen melakukan hubungan seks. Kedua, adalah ejakulasi prematur menetap yang selalu terjadi pada tiap-tiap coitus, merupakan salah satu bentuk dari neurosis sexualis, karena ini gangguan seksual maka perlu penanganan dokter. ${ }^{2}$

Ejakulasi prematur menetap inilah yang dapat menyebabkan timbulnya masalah dalam rumah tangga, karena hal tersebut merupakan kelainan yang sulit disembuhkan, sehingga istri tidak pernah memperoleh kepuasan dalam melakukan hubungan seks yang akhirnya menjadi sumber perselisihan dalam rumah tangga hingga bisa berakhir dengan perceraian. Padahal Rasulallah Saw. telah mengingatkan tentang tata cara melakukan hubungan suami istri melalui hadisnya:

Dari Talaq r.a. sesungguhnya Rasulallah Saw. telah bersabda: "Apabila seseorang kamu menggauli (mencampuri) istrinya, maka janganlah ia meninggalkan (istrinya) sehingga ia menyempurnakan akan hajatnya (keinginannya), sebagaimana laki-laki itu menyempurnakan akan hajatnya." (H.R. Ibnu 'Ady) ${ }^{3}$

Hadis ini menjelaskan bahwa jika suami melakukan hubungan seksual (coitus) dengan istrinya, maka ia harus memberikan kesempatan kepada istrinya untuk melampiaskan syahwatnya, begitu juga istri harus memberi kesempatan kepada suaminya untuk melampiaskan syahwatnya. Keduanya (suami istri) mesti sama-sama merasakan nikmat dalam penyempurnaan (hubungan seksnya) itu. 
Dalam kaitan boleh mengajukan perceraian karena hubungan seks, dapat dilihata dalam Kompilasi Hukum Islam tentang boleh mengajukan gugatan gugatan perceraian pada pasal 116 pada poin " $\mathrm{e}$ " dinyatakan bahwa apabila salah satu pihak mendapat cacat badan atau penyakit dengan akibat tidak dapat menjalankan kewajibannya sebagai suami istri. Sedangkan ejakulasi prematur yang menetap juga dapat merusak tujuan berumah tangga karena tidak terpenuhi nafkah bathin oleh suami yang disebabkan cacat/penyakit yang dimilikinya. Hal ini dapat menimbulkan masalah apakah ejakulasi prematur itu sama dengan cacat badan atau penyakit yang dimaksud dalam poin " $\mathrm{e}$ ” pasal $116 \mathrm{KHI}$.

Kajian ini juga dikaitkan dengan fiqh Syafiiyah, karena pengikut Imam Syafi'I atau yang dikenal dengan istilah Syafiiyah ditemukan masalah-masalah di atas. Jalaluddin al-Mahally dalam kitab "Qulyubi Waamirah" al-Mahally pada bab khiyar menuliskan sebagai berikut:

"Imam Syafi'i r.a. telah berpendapat: Apabila salah seorang dari suami istri mendapatkan pasangan dalan keadaan gila, penyakit jazam (kusta), penyakit supak, suami mendapatkan kelamin/ vagina istri tertutup atau tertanduk atau istri menemukan suaminya dalam keadaan lemah tatkala bersetubuh atau suami yang terpotong alat kelaminnya ditetapkan pada halhal di atas khiyar dalam pasakh nikah karena hal-hal tersebut di atas dapat menghilangkan kesenangan dalam beristimta' yang dituju dalam perkawinan." 4

Tulisan ini menelaah permasalahan apakah ejakulasi prematur dapat dijadikan sebagai alasan perceraian, baik menurut tinjauan $\mathrm{KHI}$ maupun fiqh Syafi'iyah.

\section{PEMBAHASAN}

\section{Ejakulasi Prematur dan Permasalahannya}

\section{Pengertian Ejakulasi Prematur}

Ejakulasi prematur secara umum telah dikenal dalam perkawinan, yaitu penyakit gangguan seks dimana cairan sperma terlalu cepat keluar. Untuk lebih memahami pengertian ejakulasi prematur dimaksud, akan diuraikan ke dalam dua bentuk, yakni secara etimologi dan terminologi.

Secara etimologi, ejakulasi prematur berasal dari bahasa Inggris, yaitu ejaculate (eject) dan premateur. Ejaculate (eject) berarti berseru, mengeluarkan atau memancarkan. Sedangkan premateur berarti mendahului sebelum waktunya. $^{5}$ Jadi ejakulasi prematur adalah mengeluarkan sesuatu mendahului sebelum waktunya. Dalam buku Ensiklopedi Umum, ejakulasi prematur berarti ejakulasi yang terjadi pada 
permulaan atau malahan sebelum terjadi coitus (persetubuhan). Biasanya gejala ini merupakan tanda gangguan kondisi tertentu. ${ }^{6}$

Dari pengertian-pengertian di atas, yang dimaksud ejakulasi prematur secara bahasa (etimologi) adalah ejakulasi yang terjadi pada permulaan atau sebelum terjadi persetubuhan dimana mengeluarkan sperma sebelum dikehendaki waktunya.

Secara terminology, dr. Naek L. Tobing mengertikan ejakulasi prematur sebagi kondisi dimana ejakulasi terlalu cepat atau dengan kata lain cairan sperma terlalu cepat keluar tanpa disengaja. ${ }^{7}$ Dr. Koesnadi mengartikan ejakulasi prematur adalah pencapaian orgasme (kepuasan seksual) dan ejakulasi yang terlalu cepat sebelum ia sendiri menghendakinya. ${ }^{8}$ Hanifa Wiknjosastro menyatakan, ejakulasi prematur adalah pengeluaran sperma terlampau cepat.

Ejakulasi prematur terbagi dua: pertama, ejakulasi prematur yang sementara, yaitu pengeluaran sperma yang terlalu cepat pada waktu dan keadaan tertentu yang tidak dapat dikendalikan, bersifat sementara yang sering terjadi pada coitus pertama setelah lama absen melakukan hubungan seks. Kedua, ejakulasi prematur menetap yang selalu terjadi pada tiap-tiap coitus, merupakan salah satu bentuk dari neurosis sexualis, karena ini gangguan seksual maka perlu penenganan dokter. ${ }^{9}$

Abu Zakaria menyebutkan ejakulasi prematur adalah suatu bentuk kesukaran seksuil yang banyak dialami oleh kaum laki-laki, yakni peristiwa dimana seorang suami atau laki-laki cepat mengeluarkan mani sebelum waktunya pada setiap hubungan kelamin. ${ }^{10}$ Ibnu M. Rasyid, ejakulasi prematur adalah suatu bentuk gangguan seksual yang dialami oleh pria, yakni seorang suami terlalu cepat mengeluarkan sperma pada setiap melakukan hubungan seksual. ${ }^{11}$ Koesnadi mengutip defenisi yang diberikan oleh Master dan Johnson tentang ejakulasi prematur sebagai berikut: "Bila si pria tidak dapat mengatur ejakulasi secara baik, dalam arti bila dia tidak dapat memuaskan istrinya sebanyak lebih dari 50\% dari presentasi hubungan seksual". ${ }^{12}$ Marzuki Umar Sa'abah, ejakulasi prematur yaitu pengeluaran sperma terlalu dini yang terbagi ke dalam dua jenis, yaitu ejakulasi sebelum penetrasi dan keluar mani segera setelah penetrasi. ${ }^{13}$

Dari defenisi-defenisi yang diberikan oleh pakar di atas, pada dasarnya tidak terdapat perbedaan yang prinsipil, hanya saja terdapat variasi dalam pengungkapannya. Dengan demikian dapat diambil kesimpulan bahwa pengertian ejakulasi prematur adalah suatu kondisi dimana seorang pria mengalami ejakulasi yang terlalu cepat atau cairan sperma terlalu cepat keluar tanpa disengaja dan tanpa dikehendaki oleh suami atau laki-laki. 


\section{Sebab-Sebab Terjadinya Ejakulasi Prematur}

Dalam mengemukakan sebab-sebab ejakulasi premature, terlebih dahulu dipaparkan beberapa pendapat, antara lain; dr. Koesnadi, yang menyebutkan bahwa yang menjadi faktor penyebab ejakulasi prematur adalah kebiasaan untuk berejakulasi secara cepat, antara lain: mereka yang sering ke tempat pelacuran dan hanya membutuhkan asal cepat keluar, keadaan perumahan yang sempit, dimana suami istri tidur bersama anak-anak, dan mereka harus secepat mungkin menyelesaikan hubungan kelamin tersebut, keadaan pada gland penis (kepala zakar) pria yang terlalu peka terhadap ransangan-ransangan geseran dengan vagina pada waktu hubungan seks, dan kebiasaan melakukan senggama terputus (coitus interuptus) $^{14}$

Menurut dr. Naek L. Tobing, sebab-sebab ejakulasi prematur adalah menderita penyakit kencing manis (berat/ringan), selalu tegang dan kaku (ketegangan jiwa), ketidak terusan hubungan badan (tidak teratur dalam melakukan hubungan badan) ${ }^{15}$

Abu Zakaria mengemukakan pendapatnya tentang faktor penyebab terjadinya ejakulasi prematur sebagai berikut: terlalu bernafsu sehingga pikirannya tertuju kepada persetubuhan belaka. Dengan demikian seluruh gerakan persetubuhan, apa saja yang dilakukan oleh partnernya (istri) menimbulkan ransangan yang luar biasa sampai menimbulkan kegugupan waktu persetubuhan dimulai, lesu, payah dan letih bisa mengakibatkan orang mengalami ejakulasi prematur. Orang yang baru saja bekerja berat atau memeras otaknya dalam memecahkan suatu persoalan, sebaiknya jangan melakukan persetubuhan lebih dahulu. Begitu pula bagi orang yang tertimpa musibah sehingga jiwanya menjadi goncang. Hendaknya orang-orang tersebut menunda terlebih dahulu keinginannnya sampai keletihan, kelesuan dan kepayahannya hilang. Pendek kata ketegaran jasmani dan rohani merupakan syarat untuk menghindari ejakulasi prematur.

Coitus interuptus atau senggama terputus juga sebagai penyebab ejakulasi prematur. Senggama terputus adalah mencabut penis (zakar) sewaktu dirasakan akan berejakulasi. Biasanya cara ini dilakukan oleh orang yang takut istrinya hamil. Prostat yang mengendur juga bisa mengakibatkan seseorang menderita ejakulasi prematur. Biasanya peristiwa ini banyak menimpa pada orang yang sudah tua atau berusia lanjut, tetapi gangguan penyakit atau infeksi pada prostatpun bisa mengakibatkan seseorang cepat berejakulasi. Kulit jangat penis (zakar) yang terlalu tipis. Kulit ini terdapat pada glans penis bagian luar yang 
penuh jaringan erektil. Karena terlalu tipis menyebabkan cepat sekali teransang oleh sentuhan-sentuhan yang erotis. ${ }^{16}$

Alex Comfort, William Master, dan Virginia Johnson, sebagaimana yang dikutip oleh Abu Zakaria menyatakan bahwa penyebab terjadinya ejakulasi prematur adalah keinginan berhubungan intim yang terlalu memburu dan kecemasan yang berkepanjangan. Dorongan terlalu kuat membuat seseorang tidak tenang dan seluruh syaraf dalam tubuh memburu sehingga ejakulasi tidak bisa ditahan lagi, rasa cemas atau khawatir yang terus-menerus pada saat akan melakukan atau sedang melakukan hubungan suami istri, kebiasaan atau sikap hidup yang terbiasa buru-buru dalam segala hal termasuk dalam berhubungan intim, kesehatan jiwa pria terganggu/faktor psikologis, dan hubungan emosional antara suami istri yang kurang harmonis. ${ }^{17}$

Abu Zakaria juga mengutip pendapat Havelock Ellis (seorang ahli ilmu jiwa) yang mengemukakan sebab-sebab ejakulasi prematur, antara lain, adalah adanya cacat pada alat kelamin, gangguan hormonal, kehabisan tenaga setelah ketegangan seksuail yang melampaui batas, terlalu mengumbar hawa nafsu, kecemasan, konflik-konflik mental, rasa takut, kecendrungan seksual yang abnormal. ${ }^{18}$

Selanjutnya DR. dr. Wimpie Pangkahila mengatakan penyebab ejakulasi prematur adalah sering melakukan onani tergesa-gesa, keadaan tertekan, kencing manis, perasaan takut tidak dapat memuaskan istri, dan kelelahan fisik dan mental karena tanggung jawab yang besar setelah menikah. ${ }^{19}$

Berdasarkan uraian di atas dapat diambil kesimpulan bahwa sebabsebab ejakulasi prematur adalah; pertama, faktor organik, meliputi peradangan kelenjer seks sekunder maupun ketidak seimbangan kerja hormon-hormon seks, keadaan pada glans penis (zakar) pria yang terlalu peka terhadap ransangan-ransangan geseran pada vagina pada waktu hubungan seks, kulit jangat penis (zakar) yang terlalu tipis, prostat yang mengendur, kelemahan sesudah sakit, penyakit kencing manis, gangguan fungsi kelenjer gondok, kekurangan sel darah merah, kekurangan atau gangguan gizi dan urat syaraf, obat-obatan narkotika. Kedua, faktor psikologis meliputi terlalu bernafsu, sering ke tempat pelacuran, rasa cemas atau khawatir yang terus-menerus pada saat akan atau sedang melakukan hubungan intim, ketakutan akibat dari hubungan kelamin (suami takut istrinya akan hamil), sikap hidup atau kebiasaan yang selalu buru-buru dalam segala hal, pengalaman yang menyakitkan dalam kehidupan seksual bersama pasangannya, letih, lesu dan payah, sering melakukan onani, perasaan takut tidak dapat memuaskan istri, kelelahan 
fisik dan mental karena tanggungjawab yang lebih besar setelah menikah. Ketiga, adalah faktor ekonomi, diantaranya keadaan perumahan yang sempit, dimana suami istri tidur bersama-sama dengan anak sehingga mereka secepat mungkin harus menyelesaikan hubungan kelamin tersebut dan kekurangan gizi.

\section{Akibat Ejakulasi Prematur pada Perkawinan}

Ejakulasi prematur adalah penyakit gangguan seks yang cukup banyak dibicarakan akhir-akhir ini. Gangguan seks jenis ini merupakan kondisi dimana ejakulasi terjadi terlalu cepat atau dengan kata lain, cairan sperma terlalu cepat keluar. Ini bukan suatu hal yang disengaja, tetapi penderita memang tidak bisa menahan keluarnya sperma. Kalau bisa ditahan, suami tentu ingin ejakulasi terjadi setelah hubungan seks berlansung cukup lama sehingga dapat memuaskan kedua belah pihak.

Gangguan seksual seperti ini sering mengakibatkan suami dan istri menderita. Pada umumnya ejakulasi prematur ini banyak diderita oleh orang yang hidup di kota-kota besar yang menyebabkannya bisa jadi karena perubahan social dan lainnya.

Berikut ini diuraikan akibat-akibat yang ditimbulkan oleh ejakulasi prematur terhadap perkawinan tersebut.

\section{Akibat ejakulasi prematur terhadap istri}

Satu hal yang menjadi keinginan setiap orang bila bersenggama adalah mempertahankan daya senggama sampai beberapa lama. Sebaliknya, bila senggama itu berjalan dengan cepat, niscaya kenikmatan dan kepuasan yang dirasakan tidak begitu sempurna. Sehingga akibat dari pada itu bisa menyebabkan kemurungan, terutama pihak istri. Gangguan seksual ini selanjutnya dapat mengakibatkan pihak perempuan/istri tertekan. Istri menjadi pusing dan sakit karena menderita bathin, merasakan akibat dari penyakit yang diderita oleh suami. Hal ini bisa mengakibatkan keseganan istri untuk melayani ajakan suami untuk melakukan hubungan intim. Istri akan mencari alasan untuk menghindari ajakan suami untuk berhubungan intim, seperti mengantuk, capek, letih, dan lainnya.

Suami yang selalu menahan atau menekan dorongan seks akan berakibat fatal karena kantung cairan sperma akan menjadi penuh. Apabila kantung cairan sperma sudah penuh tentu akan mengakibatkannya menjadi sensitif. Dalam melakukan hubungan intim, hanya dengan sedikit sentuhan, ejakulasi akan keluar dengan sendirinya. 
Inilah yang berlanjut terus dan akan mengecawakan kedua belah pihak karena tidak bisa merasakan kenikmatan.

Dalam kondisi seperti ini istri dapat menjadi dingin (frigid), sebagaimana yang diungkapkan oleh dr. Naek L. Tobing dalam bukunya:

"Seorang wanita yang tidak bisa menikmati hubungan seksnya secara wajar dapat mengakibatkan wanita tersebut menjadi prigit (dingin) sebab tidak pernah memperoleh kepuasan pada setiap persetubuhan, sehingga kehidupan seksuil yang normal baginya sama sekali tidak ada."

Gangguan seks ini menimbulkan penderitaan bukan saja dari segi kebutuhan biologis, tetapi juga mengakibatkan penderitaan dari segi kejiwaan. Penderitaan dari segi kejiwaan ini diantaranya istri sering marah, susah tidur, mengalami defresi, mudah tersinggung dan menderita penyakit psikosomatik dan bukan tidak mungkin istri akan mencari kepuasan lain di luar rumah.

Dalam Al-Qur'an Allah SWT menjelaskan bahwa syahwatul farj (hasrat yang kuat untuk berhubungan seksual) tidak hanya kebutuhan suami tetapi juga kebutuhan istri. Hal tersebut terungkap dalam surat AlBaqarah ayat 187 seperti yang dikemukakan diatas, bahwa suami dan istri merupakan pakaian bagi masing-masingnya. ${ }^{20}$ Maka berdasarkan ayat ini dapat dipahami bahwa antara suami istri saling membutuhkan antara satu sama lain dan saling melengkapi dalam hidup berumah tangga.

\section{Akibat ejakulasi prematur terhadap suami}

Dr. Naek L. Tobing mengatakan bahwa akibat dari ejakulasi prematur terhadap suami adalah:

"Seorang suami yang mengalami ejakulasi prematur akan selalu merasa dicemooh sehingga dapat menghilangkan rasa percaya diri dan selalu dibayangi rasa ketakutan setiap akan bersenggama. Dengan demikian membuat suami merasa rendah diri, tersiksa, kesal, gelisah, susah tidur dan harga dirinya akan menurun. Perasaan-perasaan yang demikian akan mempercepat ejakulasi, bahka bisa menimbulkan penyakit inpotensi seksual."21

Dari uraian di atas dapat dipahami bahwa secara konkrit akibat yang ditimbulkan terhadap suami adalah menimbulkan rasa tidak puas yang pada akhirnya menimbulkan gejolak kejiwaan dalam diri, dan kemudian akan mempengaruhi hubungan rumah tangganya.

Ejakulasi prematur tidak hanya melibatkan suami saja, tetapi juga istri, karena sesungguhnya kepuasan yang dapat dicapai oleh suami istri dalam bidang seksual merupakan pintu gerbang kebahagiaan dalam menuju rumah tangga yang harmonis. Ejakulasi prematur dapat berakibat 
negatif bagi pasangan suami istri, karena ejakulasi prematur merupakan gangguan seks yang dapat mengakibatkan suami istri menderita. Jika suami mengidap ejakulasi prematur, kepuasan bathin istri akan sulit dicapai sehingga tujuan dari rumah tangga sakinah, mawaddah dan rahmah akan sulit untuk diwujudkan. Apabila tujuan rumah tangga tidak dapat diwujudkan maka keutuhan rumah tangga tidak dapat dipertahankan, dan perceraianpun tidak dapat dihindari. Tetapi untuk melakukan perceraian haruslah mempunyai alasan-alasan yang tepat dan dibenarkan oleh syara' serta perundang-undangan yang berlaku di negara setempat.

\section{Tinjauan KHI terhadap Ejakulasi Prematur sebagai Alasan Perceraian}

Dalam Kompilasi Hukum Islam Indonesia, perceraian diatur dalam pasal 116 yang memuat alasan-alasan perceraian sebagai berikut: (a) salah satu pihak berbuat zina atau menjadi pemabuk, pemadat, penjudi, dan lain sebagainya yang sukar disembuhkan, (b) salah satu pihak meninggalkan pihak lain selama dua tahun berturut-turut tanpa izin pihak lain dan tanpa alasan yang syah atau hal lain diluar kemampuannya, (c) salah satu pihak mendapatkan hukuman penjara lima tahun atau hukuman yang lebih berat setelah perkawinan berlansung, (d) salah satu pihak melakukan kekejaman atau penganiayaan berat yang membahayakan pihak lain, (e) salah satu pihak mendapat cacat badan atau penyakit dengan akibat tidak dapat menjalankan kewajibannya sebagai suami istri, (f) antara suami istri terus-menerus terjadi perselisihan dan pertengkaran dan tidak ada harapan akan hidup rukun lagi dalam rumah tangga, (g) suami melanggar taklik talak, (h) Peralihan agama atau murtad yang mengakibatkan terjadinya ketidak rukunan dalam rumah tangga.

Dari alasan-alasan di atas tidak ditemui bahwa ejakulasi prematur dijadikan sebagai alasan perceraian, namun alasan yang disebutkan dalam KHI, dapat dipahami bahwa semua alasan tersebut merupakan sesuatu yang mendatangkan kemudharatan bagi pihak lain. Hal ini disebabkan adanya perbuatan atau keadaan yang terjadi pada pihak lain, dan hal lain yang mengganggu keharmonisan rumah tangga sehingga tujuan perkawinan tidak dapat diwujudkan.

Sebagaimana telah dijelaskan dalam pembahasan terdahulu, ejakulasi prematur merupakan gangguan seks pada pihak suami yang bisa mengakibatkan tidak terwujudnya tujuan rumah tangga. Dalam hal ini timbul permasalahan, dapatkah ejakulasi prematur dijadikan sebagai alasan perceraian setelah suami diberi kesempatan untuk berobat? KHI 
secara harfiah memang tidak menyebutkan dengan tegas bahwa ejakulasi prematur dijadikan sebagai alasan perceraian, namun bila ditinjau lebih mendalam dari alasan-alasan perceraian yang dikemukan dalam KHI dalam pasal 116 di atas pada poin " $\mathrm{e}$ ", dapat dipahami secara tersirat bahwa ejakulasi prematur bisa dijadikan alasan perceraian, karena termasuk ke dalam salah satu kategori alasan-alasan perceraian yang disebutkan dalam pasal 116 KHI. Hal ini dipahami dari segi tidak terpenuhinya kebutuhan bathin dari pihak istri, karena ejakulasi prematur yang dialami oleh suami tidak dapat mendatangkan titik klimaks kepuasan bagi pihak istri dalam melakukan hubungan seksual.

Bila seorang istri tidak terpenuhi nafkah bathinnya oleh suami, dapat mengakibatkan istri mencari jalan lain untuk memenuhi kebutuhan bathin. Keadaan seperti ini sangat membahayakan, baik bagi suami, istri, serta anak-anak. Pada hakekatnya Rasulallah saw. telah memberikan gambaran dalam melakukan hubungan seksual yang baik, sehingga dapat memuaskan kedua suami istri sebagaimana sabda Nabi saw:

Dari Talaq r.a. sesungouhnya Rasulallah Saw. Telah bersabda: "Apabila seseorang kamu menggauli (mencampuri) istrinya, maka janganlah ia meninggalkan (istrinya) sehingga ia menyempurnakan akan hajatnya (keinginannya), sebagaimana laki-laki itu menyempurnakan akan hajatnya." (H.R. Ibnu 'Ady) ${ }^{22}$

Dari hadis di atas dapat diambil pengertian bahwa jika suami melakukan hubungan seksual (senggama), dengan istrinya maka ia harus memberikan kesempatan kepada istrinya untuk memuaskan syahwatnya, begitu juga istri harus memberikan kesempatan kepada suaminya untuk melepaskan syahwatnya. Jadi keduanya (suami istri) harus sama-sama merasakan nikmatnya dalam percampuran (hubungan seksnya) itu. Tetapi suami yang mengalami ejakulasi prematur hanya merasakan kepuasan sendiri, tidak bagi istri.

Dalam KHI pasal 116 di atas pada poin " $\mathrm{e}$ " dinyatakan bahwa, "salah satu pihak mendapat cacat badan atau penyakit dengan akibat tidak dapat menjalankan kewajiban sebagai suami atau istri".

"Apabila suami menderita impoten (lemah yahwat) diberi kesempatan untuk berobat selama satu tahun guna menyembuhkan penyakitnya. Apabila dalam waktu satu tahun tidak kunjung sembuh istri berhak mengajukan cerai kepada suaminya".23

Sebagaimana langkah yang diambil oleh Umar bin Khattab, khalifah ke-dua, bahwa beliau mengambil keputusan bahwa orang yang impoten (lemah syahwat) atau lemah tatkala melakukan hubungan seksual agar diberi kesempatan berobat selama satu tahun guna 
menyembuhkan penyakitnya. Hal ini bila dihubungkan dengan ejakulasi prematur maka dapat dimasukkan pada poin " $\mathrm{e}$ ", karena bila yang disebutkan itu berakibat tidak terpenuhinya nafkah bathin masing-masing pihak maka ejakulasi prematurpun berakibat tidak terpenuhinya nafkah bathin salah satu pihak yaitu nafkah kepada istri.

Hal ini sesuai dengan apa yang diungkapkan oleh Sayid Sabiq dalam Figh Sunnah tentang praktek yang berlaku dalam peradilan Mesir. Praktek yang sekarang berjalan dalam peradilan Mesir sesuai dengan Undang-Undang pasal 9 tahun 1920:

"Bahwa perempuan berhak membatalkan perkawinan, jika suaminya mengalami cacat menahun yang tidak mungkin sembuh lagi atau mungkin sembuh tapi lama sekali sedangkan ia tidak dapat hidup bersama dengannya kecuali mengalami kesulitan-kesulitan. Cacat-cacat ini meliputi segala macam cacat seperti gila, kusta dan burik, baik cacat suami itu terjadi sebelum perkawinan tetapi ia tidak tahu atau terjadi sesudah perkawinan tetapi ia tidak menyenanginya. Jika ia kawin dan dan sebelumnya sudah tahu cacatnya/penyakitnya atau cacatnya terjadi sesudah perkawinan dan ia mau menerimanya, baik dengan terang-terangan atau diam-diam sesudah mengetahui hal tersebut, maka ia tidak boleh membatalkan perkawinannya. Jika ia membatalkan perkawinan itu dianggap sebagai thalak ba'in dan untuk mengetahui cacat atau penyakit serta beberapa jauh akibat-akibat tidak baiknya hendaklah diminta bantuan orang-orang yang berpengalaman." 24

Walaupun secara tegas tidak disebutkan bahwa suami yang mengidap penyakit ejakulasi prematur dapat dijadikan sebagai alasan perceraian, tetapi secara tersirat KHI telah menetapkan bahwa ejakulasi prematur dapat dijadikan sebagai alasan perceraian dengan ketentuan suami yang mengalami ejakulasi prematur diberi kesempatan terlebih dahulu untuk mengobati penyakitnya. Jika tidak sembuh juga dalam rangka waktu tertentu, istri berhak mengajukan cerai kepada suaminya.

Hal ini dapat dipahami bahwa dalam KHI pada pasal 116 poin " $\mathrm{e}$ " dinyatakan: "Salah satu pihak mendapat cacat badan atau penyakit dangan akibat tidak dapat menjalankan kewajibannya sebagai suami istri". Kalimat cacat badan atau penyakit dengan akibat dapat menghalangi kewajibannya sebagai suami istri menunjukkan bahwa salah satu diantara penyakit tersebut adalah ejakulasi prematur, karena penyakit ini dapat menghalangi tugas masing-masingnya selaku suami istri.

Suami yang mengidap penyakit ejakulasi prematur ini dapat menimbulkan kerugian pada istri dan pada dirinya sendiri. Kerugian pada pihak istri adalah tidak terpenuhi hak istri oleh suami dalam nafkah 
bathin, karena ejakulasi prematur kepuasaan yang dicapai dalam melakukan hubungan seksual hanya kepuasan sepihak yaitu pada pihak suami, sedangkan tujuan yang dimaksud oleh perkawinan adalah kepuasan pada masing-masing pihak guna menuju rumah tangga sakinah, mawaddah dan rahmah. Kerugian pada diri suami itu sendiri adalah timbulnya rasa minder atau rendah diri di mata istri yang akan membawa kepada penyakit yang sangat menakutkan yaitu penyakit stress. Bila semua ini terjadi maka secara logika dapat dipastikan bahwa rumah tangga tidak akan memberikan ketentraman kepada kedua belah pihak, bahkan dapat diduga rumah tangga tersebut tidak akan bertahan lama.

\section{Ejakulasi Prematur sebagai Alasan Perceraian menurut Fiqh Syafi'iyyah}

Perceraian adalah perbuatan yang halal tetapi sebagai alternatif terakhir bila tidak ada lagi jalan yang lebih baik. Menurut mazhab Syafi'iyah, untuk melakukan suatu perceraian hendaklah mempunyai alasan yang tepat. Alasan yang tepat yaitu hal-hal yang mengganggu dan menghalangi terlaksananya hak dan kewajiban sehingga rumah tangga sakinah, mawaddah dan rahmah tidak akan tercapai, sebagaimana penjelasan di atas.

Dalam Fiqh Syafi'iyah, diantara hal yang dapat dijadikan sebagai alasan perceraian adalah "suami lemah tatkala bersetubuh" sehingga ia tidak dapat menjalankan kewajibannya sebagai suami. Bila dihubungkan alasan ini dengan ejakulasi prematur maka keduanya mempunyai unsur yang sama yaitu: bila alasan yang disebutkan oleh Syafi'iyah itu mengakibatkan tidak terpenuhinya kebutuhan suami atau istri maka ejakulasi prematur pun mengakibatkan tidak terpenuhinya kebutuhan suami atau istri, khususnya dalam pemenuhan nafkah bathin istri.

"Kewajiban memberikan nafkah bagi seorang suami terhadap istrinya ada dua macam, yaitu nafkah lahir dan bathin. Nafkah lahir berupa, makan, minum, pakaian dan tempat tinggal. Sedangkan nafkah bathin ialah menciptakan suasana mesra dan kasih sayang serta bahagia terhadap seorang istri. Dengan demikian usaha memuaskan sang istri dalam melakukan hubungan seksual berarti termasuk pemberian nafkah bathin bagi seorang suami terhadap sang istri." 25

Menurut pendapat mazhab Syafi'iyah, istri boleh melakukan khiyar atau fasakh nikah bila seorang suami lemah ketika melakukan coitus (senggama) sebagaimana yang terdapat dalam kitab Qulyubi wa Amirah sebagai berikut: 
Imam Syafi'I r.a. telah berpendapat: Apabila salah seorang dari suami istri mendapatkan pasangan dalam keadaan gila, penyakit jazam (kusta), penyakit supak, suami mendapatkan kelamin/vagina istri tertutup atau tertanduk atau istri menemukan suaminya dalam keadaan lemah tatkala bersetubuh atau suami yang terpotong alat kelaminnya ditetapkan pada hal-hal di atas khiar dalam pasakh nikah karena hal-hal tersebut di atas dapat menghilangkan kesenangan dalam beristimta' yang dituju dalam perkawinan. ${ }^{26}$

Berdasarkan uraian di atas dapat dinyatakan bahwa bila ada halhal yang akan menghalangi pihak suami untuk memenuhi nafkah bathin istri maka hal tersebut dapat dijadikan sebagai alasan untuk mengajukan fasakh nikah. Bila dihubungkan pendapat Syafi'iyah tentang "lemahnya seorang suami" ketika coitus dengan ejakulasi prematur maka kedua hal tersebut mempunyai kesamaan maksud, yaitu sama-sama dapat menghalangi suami untuk memenuhi kebutuhan bathin istri. Berdasarkan hal tersebut dan alasan-alasan yang telah penulis uraikan, maka ejakulasi prematur dapat diterima sebagai alasan perceraian dalam bentuk fasakh menurut pandangan Syafi'iyah.

\section{SIMPULAN}

Allah SWT melarang melakukan zina dan menghalalkan pernikahan supaya manusia tidak mengumbar hawa nafsu mereka tanpa ada aturan yang mengaturnya. Karena itulah salah satu tujuan perkawinan adalah menghindarkan diri dari perbuatan haram. Akan tetapi, jika suami mengidap ejakulasi prematur tentulah dapat merusak tujuan perkawinan. Tidak terpenuhinya kebutuhan bathin istri secara naluriah akan memberikan peluang untuk melakukan perbuatan yang diharamkan tersebut. Sehingga tujuan perkawinan sakinah, mawaddah dan rahmah tidak akan dapat diwujudkan karena tidak terlaksananya hak dan kewajiban secara benar.

Dalam KHI, ejakulasi prematur dimasukkan dalam alasan perceraian bagi istri dalam bentuk gugat cerai atau khulu'. Sementara dalam mazhab Syafi'i ejakulasi prematur dijadikan alasan bolehnya melakukan perceraian dengan jalan fasakh. Walaupun gugat cerai dan fasakh masuk dalam kelompok putusnya perkawinan, namun keduanya mempunyai dampak hukum yang berbeda.

Bila diteliti hadis tentang gugat cerai atau khulu', maka khulu' dilakukan bukan karena adanya kesalahan suami yang menyebabkan kemudharatan pada istri atau suami meninggalkan kewajibannya. Hadis tentang khulu'27 lebih pada ketidaksenangan istri pada suami yang akan mengganggu kenyamanan dalam rumah tangga. 


\section{Endnotes:}

1 Hanifah Wiknjosastro, Ilmu kandungan, Jakarta: Yayasan Bina Pustaka Sarwono Prawirohardjo, 1994, Edisi 2, h. 611

2 Ibid, h. 612

3 Sayyid Ahmad al-Hasymi, Mukhtarul Hadis an-Nabawiyah wal-Hikmatul Muhammadiyah, Semarang: Usaha Keluarga, tt, h. 11

4 Jalaluddin al-Mahally, Qulyubi Waamirah, Indonesia: Maktabah Darul al-Kutub alArabiyah, t.th, juz III, h. 261-262

5 Tigor Pangaribuan, Kamus Populer Lengkap, Bandung: Pustaka Setia, 1997, Cet. Ke 2, h. 46

6 Ensiklopedi Umum, Yogyakarta: Penerbit kanisius, 1993, Cet. Ke 10, h. 298

7 Naek L. Tobing, Seks dan Problemanya, Jakarta: Pustaka Kartini, 1994, Cet. Ke 2, h. 112

8 Koesnadi, Op.Cit, h. 81

9 Hanifah Wiknjosastro, Op. Cit, h. 611

10 Abu zakaria, Mengawetkan Cinta Kasih Suami Istri, Yogyakarta: CV. Aneka, 1997, Cet. Ke 7, h. 148

11 Ibnu M. Rasyid, Mahligai Perkawinan Butir-Butir Mutiara Cinta, Pekalongan: CV. Bahagia, 1996, Cet. Ke 6, h. 146

12 Koesnadi, Op.Cit, h. 81

13 Marzuki Umar Sa'adah, Seks dan Kita, Jakarta: PT. Gema Insani Press, 1997, h. 138

14 Koesnadi, Op.Cit., h. 82

15 Naek L. Tobing, Op.Cit., h. 119-127

16 Abu Zakaria, Op.Cit., h. 149-150

17 Ibid., h. 115

$18 \quad$ Ibid., h. 111

19 Wimpie Pangkahila, Kumpulan Dialog Wanita dan Seks, Jakarta: PT. Intisari Mediatama, 1998, h. 69

20 Mahmud Yunus, Terjemahan Al-Qur'an al-karim, Bandung: Al-Ma'arif, 1989, h. 366

21 Naek L. Tobing, Op. Cit., h. 127

22 Sayyid Ahmad al-Hasymi, Mukhtarul Hadis an-Nabawiyah wal-Hikmatul Muhammadiyah, Semarang: Usaha Keluarga, tt, h. 11

23 Nina Surtiretna, Bimbingan seks dalam Pandangan Islam dan Medis, Bandung: PT. Remaja Rosda Karya, 1996, h. 135

24 Sayid Sabiq, Fiqh Sunnah, Penerjemah Moh. Nabhan Husein, bandung: PT. AlMa'arif, 1990, jilid 6, h. 84

25 Ibnu M. Rasyid, Mahligai Perkawinan, Semarang: CV. Bahagia, 1996, h. 101

26 Jalaluddin al-Mahally, Qulyubi Waamirah, Indonesia: Maktabah Darul al-Kutub alArabiyah, t.th, juz III, h. 261-262

27 Hadis tentang khulu' hadits Ibnu Abbas RA yang artinya: “Isteri Tsabit bin Qais bin Syammas mendatangi Nabi SAW seraya berkata: "Wahai Rasulullah, aku tidak membenci Tsabit dalam agama dan akhlaknya, Aku hanya takut kufur". Maka Rasulullah SAW bersabda: "Maukah kamu mengembalikan kepadanya kebunnya?", Ia menjawab, "Ya", maka ia mengembalikan kepadanya dan Rasulullah SAW memerintahkannya, dan Tsabit pun menceraikannya" HR Al-Bukhari dapat dilihat dalam al-Sanna' ani, Subul al-Salam, juz III, h. 143 


\section{DAFTAR PUSTAKA}

Ensiklopedi Umum. Yogyakarta: Penerbit Kanisius, Cet. Ke 10. 1993

Hasymi, Sayyid Ahmad al-. t.th. Mukhtarul Hadis an-Nabawiyah walHikmatul Muhammadiya. Semarang: Usaha Keluarga.

Mahally, Jamaluddin al-. t.th. Qulyubi Waamirah, juz III, Indonesia: Maktabah Darul al-Kutub al-Arabiyah, t.th.

Pangaribuan, Tigor. 1997. Kamus Populer Lengkap. Bandung: Pustaka Setia, Cet. Ke-2.

Pangkahila, Wimpie. 1998. Kumpulan Dialog Wanita dan Seks. Jakarta: PT. Intisari Mediatama.

Rasyid, Ibnu M.. 1996. Mahligai Perkawinan Butir-Butir Mutiara Cinta. Pekalongan: CV. Bahagia. Cet. Ke 6.

Sa'adah, Marzuki Umar. 1997. Seks dan Kita. Jakarta: PT. Gema Insani Press.

Sabiq, Sayid. 1990. Fiqh Sunnah, jilid 6. Penerjemah Moh. Nabhan Husein. Bandung: PT. Al-Ma'arif.

Shan'aniy, al. Subul al-Salam. Juz III

Surtiretna, Nina. 1996. Bimbingan seks dalam Pandangan Islam dan Medis. Bandung: PT. Remaja Rosda Karya.

Tobing, Naek L.. 1994 . Seks dan Problemanya, Jakarta: Pustaka Kartini. Cet. Ke-2.

Wiknjosastro, Hanifah. 1994. Ilmu kandungan, Jakarta: Yayasan Bina Pustaka Sarwono Prawirohardjo. Edisi 2.

Yunus, Mahmud. 1989. Terjemahan Al-Quran al-karim. Bandung: Al-Ma'arif

Zakaria, Abu. 1997. Mengawetkan Cinta Kasih Suami Istri. Yogyakarta: CV. Aneka, Cet. Ke 7. 